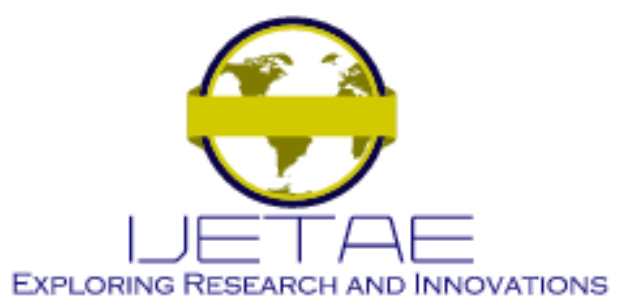

International Journal of Emerging Technology and Advanced Engineering

Website: www.ijetae.com (E-ISSN 2250-2459, Scopus Indexed, ISO 9001:2008 Certified Journal, Volume 11, Issue 10, October 2021)

Manuscript Received: 04 June 2021, Received in Revised form: 10 October 2021, Accepted: 24 October 2021

DOI: 10.46338/ijetae1021_01

\title{
Social Media Based Decision Support Model To Solve Indonesian Waste Management Problem: An Improved Version
}

\author{
Christopher Michael ${ }^{1}$, Ditdit Nugeraha Utama ${ }^{2}$ \\ ${ }^{1,2}$ Computer Science Department, BINUS Graduate Program - Master of Computer Science, Bina Nusantara University \\ Jakarta, Indonesia 11480
}

\begin{abstract}
Twitter is a commonly used social media and can sometimes picture an entire situation especially environmental issues like waste management. Machine learning and sentiment analysis tools have also been used in many cases around the world and has produced useful results to assist decision making models. In this research Decision Support Model (DSM) and Sentiment Analysis with the help of Naïve Bayes Theorem was used to analyze the waste management case in Indonesia and find out how much improvement is needed in the current situation. The research has found that severe improvements in all of the 5 aspects analyzed is needed to elevate the waste management quality to the next level, especially with a low overall score of 45.29 .
\end{abstract}

Keywords - machine learning, social media, fuzzy logic, sentiment analysis

\section{INTRODUCTION}

Among every social media around the world the ones that are largely used is Twitter. It's a social media that allows us to share any forms of thought in many issues around us, from as simple as life choices, until global issues entertainment, technology, and environment. Like other social medias in general, it can be a very useful tool used by multinational firms, medium sized agencies, nonprofit organizations and governments alike [1]. Approximately $91 \%$ of users made their accounts and tweets public, therefore there are an abundance of data that are available to researchers [2]. Researching via this social media however, could be a hit and miss at times because the large number of tweets that contains misspellings, abbreviations, or tweets that just contains pictures and links. Too many of these can result in only a fraction of legitimate tweets being able to be researched.

Waste management is one of the environmental issues that are very often discussed in many cities. One of the discussions is about how poor managements can lead to environmental relates issues, such as pollutions, diseases caused by them and floods.
Whether it is plastic, food or solid waste, it is something that so many researchers around the world keeps exploring using different methods. Researches involving waste management has been done from various cases and various locations. [3] did a research in India regarding its municipal solid waste management, evaluating its strengths and weaknesses including the door to door collection policy. [4] conducted research about the weaknesses of the waste management policy in Xiamen, China, since 2000. [5] analyzed the solid waste management in Sri Lanka, addressing its strengths and weaknesses and steps that could be done onwards.

Because of the abundance of social media users waste management is an important topic to be researched. By presenting the results of progress being done by governments and citizens it will serve as a feedback in order to increase the awareness of proper waste management policy and implementation to prevent further disasters and improve the image of their living place. Some other cases of social media's involvements includes assisting third world countries in reacting to disasters [6] and identifying what makes one brand being able to keep loyal consumers [7]. There is also the case of social media impacting food waste behavior, which was via the company's attempt to remind its buyers about the matter [8] and predict the behavior of recycling activities [9]. With so many different issues being talked in social medias, it is imperative that the opportunity to remind the people cannot be missed, else worse things like the overabundance of landfill will be inevitable. This research is aimed to not only improve the previous researches on the same field and using social media as the method of their analysis, but also raise the awareness of the public, especially in Indonesia, about the waste management habits that could have implications in the future. 


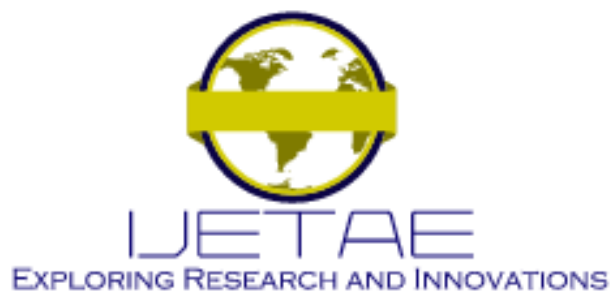

International Journal of Emerging Technology and Advanced Engineering

Website: www.ijetae.com (E-ISSN 2250-2459, Scopus Indexed, ISO 9001:2008 Certified Journal, Volume 11, Issue 10, October 2021)

In this research Twitter will be the source of the data. Improved methods that operated in building decision support model (DSM) will also be mentioned in this research; including fuzzy logic, sentiment analysis, and mathematical model. The aim of this research is to improve the previous works by involving previous guidelines in the waste management field and social media type researches and utilizing the machine learning tool to analyze people's sentiments in the social media, so with the support of an existing sentiment analysis tool available, a better result of the problem can be obtained and better feedback can be generated to fix the issue once and for all.

The previous research of this case has been done by [10] highlighting the similar issue and was able to highlight the problems in the Indonesian waste management quality. However, during the parameter defining process, the research did not use any sentiment analysis algorithms to assist in their parameters finding and utilized questionnaires to assist the decision making process. This research would use the help of previous researches in utilizing the sentiment analysis algorithm as an alternative to find the more accurate set of parameters for this research. By utilizing machine learning, it is hoped that concrete results can be generated in shorter amount of time.

\section{LITERATURE REVIEW}

This research is a continuation from [10]. In that research the paper used up to 5 parameters to determine the final waste management quality, but no clustering algorithm was used in the research. Another research [11] also used a similar method of decision support but for corruption case, and was able to identify one parameter that heavily determines the severity of the corruptions in Indonesia. Modifications will be performed in the parameter finding process in form of sentiment analysis algorithms and a different method to collect input values, which, in previous research, used the questionnaire.
DSM is a very commonly researched model and has seen plenty of implementations. [12] constructed DSM to support group decision making problems, focusing on the consistency improvements. [13] utilized fuzzy preference programming, FTOPSIS and aggregation method to create DSM to fix supply chain management problem. [14] used several mathematical models in their research to solve decision making problem in making metallic parts. Unfortunately, optimum results were not possible for them due to several invalid data. [15] used a DSM consisting of probabilistic linguistic term sets, probabilistic linguistic integrated clouds, and a mean operator to be used in the case of Tripadvisor.com hotel selection. [16] used DSM to solve the case of multi-criteria instrumental evaluation of orthotics results with foot pathology. During the research, they used hierarchic process analysis method to develop the models and matrix form as one of the aspects in their decision model.

Alongside Twitter, researches of social medias in general have been done multiple times. [17] analyzed the usage of Facebook and Twitter during the Haitian Earthquake in 2010 using methods such as Chi-Square. The research resulted in the proof that the social media was utilized well by the nonprofit organizations but there was a lot of room for improvement for the media's platform usage, since it was used more for the clickbaits and description of the disaster and not the relief efforts. [18] used Support Vectoring Machine to analyze tweets containing slang words. The sentiment analysis also used conditional random fields in building the model. [19] developed PoliTwi, a system that includes hashtag analyzer and emoticon analyzer, to analyze when will Twitter generate emerging political topics compared to Google Trends. 


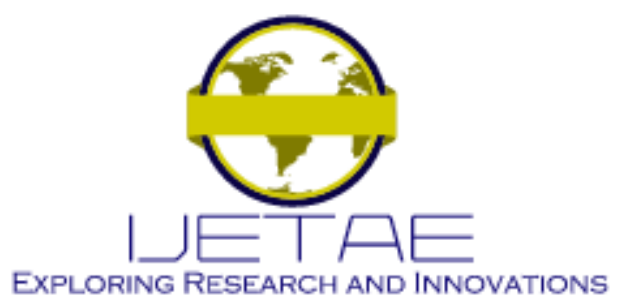

International Journal of Emerging Technology and Advanced Engineering

Website: www.ijetae.com (E-ISSN 2250-2459, Scopus Indexed, ISO 9001:2008 Certified Journal, Volume 11, Issue 10, October 2021)

Table 2:

References for DSM related researches

\begin{tabular}{|c|c|c|c|}
\hline Source & Field & Method & Results \\
\hline [12] & $\begin{array}{l}\text { GDM process in } \\
\text { general }\end{array}$ & $\begin{array}{l}\text { Multiplicative } \\
\text { preference } \\
\text { relations, } \\
\text { consensus } \\
\text { index }\end{array}$ & $\begin{array}{l}\text { Testing } \\
\text { Successful }\end{array}$ \\
\hline [13] & $\begin{array}{l}\text { Multi-person } \\
\text { emergency } \\
\text { decision support, } \\
\text { Numerical } \\
\text { Dataset }\end{array}$ & $\begin{array}{l}\text { Distance-based } \\
\text { multi-criteria } \\
\text { GDM model }\end{array}$ & $\begin{array}{l}\text { Great potential } \\
\text { of the algorithm } \\
\text { discovered }\end{array}$ \\
\hline [14] & $\begin{array}{l}\text { Manufacturing } \\
\text { processes from } \\
\text { energy } \\
\text { consumption } \\
\text { perspective }\end{array}$ & $\begin{array}{l}\text { Mathematical } \\
\text { model }\end{array}$ & $\begin{array}{l}\text { Experiment } \\
\text { discovered } \\
\text { factors affecting } \\
\text { manufacturing } \\
\text { process choices }\end{array}$ \\
\hline [15] & $\begin{array}{l}\text { Tripadvisor.com } \\
\text { hotel selection }\end{array}$ & $\begin{array}{l}\text { Probabilistic } \\
\text { Linguistic } \\
\text { Integrated } \\
\text { Cloud, } \\
\text { Heronian mean }\end{array}$ & $\begin{array}{l}\text { Specific } \\
\text { variables that } \\
\text { can change hotel } \\
\text { decision flow } \\
\text { discovered }\end{array}$ \\
\hline [16] & Orthotics results & $\begin{array}{l}\text { Hierarchies, } \\
\text { Matrix Forms }\end{array}$ & $\begin{array}{l}\text { Limitations } \\
\text { found, caused by } \\
\text { poorly } \\
\text { formalized } \\
\text { indicators }\end{array}$ \\
\hline [10]. & $\begin{array}{l}\text { Waste } \\
\text { Management }\end{array}$ & $\begin{array}{l}\text { Fuzzy Logic, } \\
\text { Questionnaires }\end{array}$ & $\begin{array}{l}\text { Testing found } 5 \\
\text { parameters and } \\
\text { assigned } \\
\text { decision values } \\
\text { to each }\end{array}$ \\
\hline [11] & Corruption Case & Fuzzy Logic & $\begin{array}{l}\text { Testing decided } \\
\text { values for } \\
\text { parameters set } \\
\text { and singled out } \\
\text { one parameter as } \\
\text { a highly } \\
\text { deciding factor }\end{array}$ \\
\hline
\end{tabular}

\section{THEORIES}

\section{A. Sentiment Analysis}

Sentiment analysis is a method of text analysis where we process subjective information from other users to conclude a positive or negative sentences. This method is often done on sites that is full opinions like review sites and social medias [20].
There are several approaches that can be done for sentiment analysis, such as automatic modes using Naïve Bayes, Support Vectoring Machine or using a set of rules defined manually. Sentiment analysis process is comprised of 2 stages: data training and data prediction. Both process involves using the model created to make classification of the text data into categories, such as "Positive" or "Negative". Training process is needed to ensure the weight being assigned to the model so it can analyze the eventual data based on the training set given.

\section{B. Naive Bayes Classifier}

Naïve Bayes is an algorithm based on the Bayes theorem. It is used to construct classifiers and is regarded as one of the simpler algorithms for classifications (Rennie et al., 2003). The Naïve Bayes algorithm is based on the principle that one's attributes does not correlate with the other attributes in deciding the probability of an object's category (Rish \& Rish, 2001). This form of classifier is usually effective with supervised training method and can be trained at a much quicker rate compared to other classifiers. Forms of Naïve Bayes includes Gaussian, Multinomial and Bernoulli, with the Gaussian Bayes mainly associated with text level classifications. One formula indicating probability of event A given the $\mathrm{B}$ event already occurring can be described in equation (1).

$$
P(A \mid B)=\frac{P(B \mid A) \cdot P(A)}{P(B)}
$$

\section{Corpora}

Corpora is a method to create a sentiment lexicon for various text related researches including Sentiment Analysis (Stuart et al., 2018). This approach works by combining a phrase or set of words that is universally positive, neutral or negative and combine them with other sentences, and determine the overall sentiment of the sentence. The importance of this method is that despite the method producing less complete list compared to the other automated method, "dictionary", it can produce more unpredictable results due to the sentences containing more than one sentiments in it.

\section{Natural Language Toolkit}

Natural Language Toolkit (NLTK) is a Python toolkit developed by [21], and is currently used by many subsequent python plugins related to natural language processing including Textblob. 


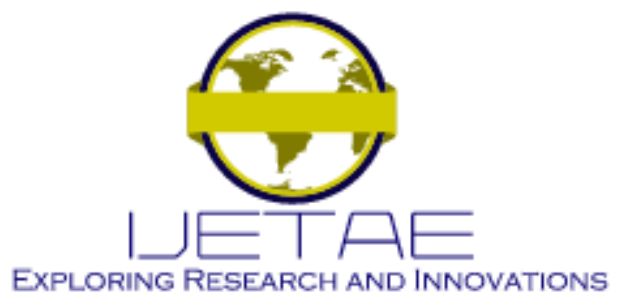

International Journal of Emerging Technology and Advanced Engineering Website: www.ijetae.com (E-ISSN 2250-2459, Scopus Indexed, ISO 9001:2008 Certified Journal, Volume 11, Issue 10, October 2021)

There are 3 applications that determine the function of this toolkit: Assignments, which the ability of users completing task after tasks with it and eventually being able to modify the toolkit and use it to build a model based on it, Demonstrations, which highlights NLTK's graphical interface in showing the algorithm's work, and projects, which highlights the capability of providing students with framework for advanced type projects.

\section{E. Fuzzy Logic}

Fuzzy Logic is an algorithm implemented by [22]. It is an algorithm used to solve decision making in terms of truth value, which is a number between 0 and 1 . The logic still presents the 0 and 1 value but only during the most extreme cases. The fuzzy logic process includes: fuzzifying crisp inputs into membership values, executing the rules being applied to the fuzzy functions, and reverting the values into another crisp output (defuzzification). Fuzzy sets are usually defined by triangular or trapezoid functions (sample of trapezoid function in Image 1), both had the peak membership value representing 1 and slopes to represent other values according to the. Fuzzy logic has a set of different operators compared to standard Boolean operators, and is also called the "Zadeh Operators". The changes from the Boolean operators are as follows:

1. $\operatorname{AND}(\mathrm{x}, \mathrm{y})$ becomes $\operatorname{MIN}(\mathrm{x}, \mathrm{y})$

2. OR $(\mathrm{x}, \mathrm{y})$ becomes $\operatorname{MAX}(\mathrm{x}, \mathrm{y})$

3. $\operatorname{NOT}(\mathrm{x}, \mathrm{y})$ becomes $1-\mathrm{x}$

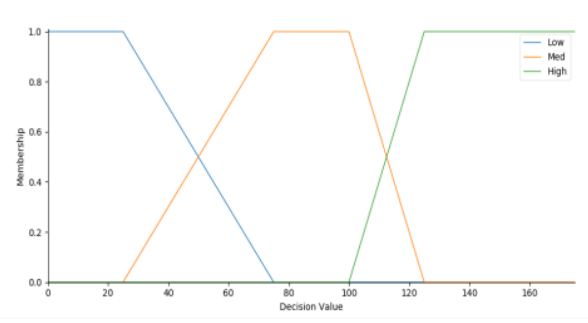

Image 1: Trapezoid Fuzzy Set

The fuzzification process is about converting crisp numerical input values and applying degrees to determine the categories and its limits (example via Image 1). The crisp numerical input values, which can be any range (in this sample: 0 - 160), will then be converted into $0-1$ value, also known as the antecedent value. One of the most commonly used methods for the fuzzification process is linear interpolation.
Linear interpolant is a straight line being drawn between two points given their coordinates being $\left(x_{0}, y_{0}\right)$ and $\left(x_{1}, y_{1}\right)$. The basic equation of linear interpolation is shown in Equation (2).

$$
\frac{y-y_{0}}{x-x_{0}}=\frac{y_{1}-y_{0}}{x_{1}-x_{0}}
$$

Via a set of user defined rules, each antecedent will undergo process to form a final value based on the interactions between them. The prerequisites are determined by user via logic operators mentioned previously and it could take as many antecedents as the user desires. The Table 1 shows the operations for each operator (AND, OR and NOT respectively) used by the user.

Table 1:

The operators in Fuzzy Logic

\begin{tabular}{|c|c|}
\hline Operator & Operation \\
\hline MIN & $\mu_{A \cap B}(x)=\mu_{A}(x) \wedge \mu_{B}(x)$ \\
\hline MAX & $\mu_{A \cup B}(x)=\mu_{A}(x) \vee \mu_{B}(x)$ \\
\hline $1-\mathrm{x}$ & $\mu_{\bar{A}}(x)=1-\mu_{A}(x)$ \\
\hline
\end{tabular}

Defuzzification process involves converting the results of the conversion process of the antecedents and converting them to crisp output values (consequents) [23]. The output values' range and classes are also determined by user. Various methods can be done for the defuzzification process, such as Bisector of Area (BOA), Adaptive Integration (AI), Fuzzy Mean (FM) and Influence Value (IV). But the most commonly used method is Center of Gravity (COG). Basically, after summing up the results of the rules, the method is to find the point $x$, the center of the graph represented by a vertical line dividing the shapes into 2 equal masses. The mathematical equation is displayed via Equation (3); where $\mathrm{x}$ is the $\mathrm{x}$ coordinate of the gravity center and $\mu_{c}(x) d x$ denotes the area of the region with the $\mu_{c}$ curve as the boundaries [24].

$$
x=\frac{\int x \cdot \mu_{c}(x) d x}{\int \mu_{c}(x) d x}
$$

\section{METHODOLOGY}

\section{A. Overview}

The earlier process of this research involves studying previous researches related to sentiment analysis, waste management and decision support model in order to aid the parameter defining process later in the research. 


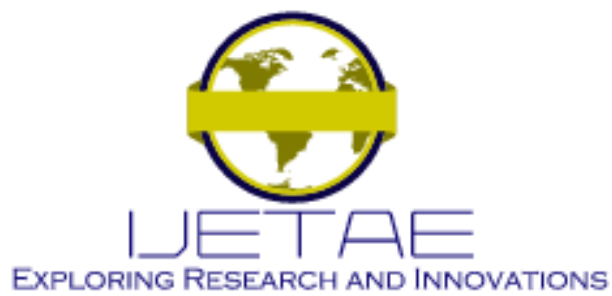

International Journal of Emerging Technology and Advanced Engineering Website: www.ijetae.com (E-ISSN 2250-2459, Scopus Indexed, ISO 9001:2008 Certified Journal, Volume 11, Issue 10, October 2021)

The subsequent processes include filtering and cleansing of user's opinions on Twitter before utilizing the sentiment analysis to classify the cleansed tweets into values to serve as the inputs for the DSM, which consists of fuzzy logic and mathematical model. This can result of more than one parameter being generated as the final value that will decide the quality of waste management. In [10] for example, there were 5 parameters generated ranging from public's awareness to governmental actions to punish those who violates the environmental rules. Those categories cover the citizens' behaviors, infrastructures and governmental actions to enforce the rules.

\section{B. Research Stages}

This research is divided into 4 steps (Image 2). Step number one is "Literature Studying", which is reviewing literatures related to the research. In this case the literatures being reviewed will be the ones related to the DSM being used and similar researches involving waste management, social media and sentiment analysis. There are various websites as sources of the related papers such as Elsevier and ScienceDirect. Several keywords that are going to be used in this process includes "Waste", "Waste Management", "Decision Support", "Social Media", "Sentiment Analysis" and "Twitter".

Once the it's done, we will create the model that is going to be used in this research. Firstly the model extracts tweets from the Twitter website using a free browser plugin called Web Scraper [25], which will extract text data from the Twitter site according to the range and keyword desired. The process can take a long time depending on how many tweets are available via results. The language that will be used in this extraction is Bahasa and the time range of the tweets will be within one year from when the scraping will begin. Raw tweets extracted from this step will be preprocessed via text cleansing methods such as tokenization, stemming, case folding and stopword removal. Several instances of words that needs to be removed also includes swearing, typos that often occurs or tweets that are basically just advertisements or spams (containing "UP! UP! UP!" or "Jasa xxx").

The preprocessed text will then be analyzed via sentiment analysis tools. The analysis model will acquire data to be trained and the weights obtained will be used to classify the actual data.
It is crucial at this stage that the tweets have to already been cleaned of unnecessary words. After the model is created and trained, the implementation will commence using the most recent Twitter data extracted and parameterizing of the tweets into several categories will commence. Once the parameterizing process is complete, data will be gathered using either questionnaire or relevant official data provided by government. The results gathered will be calculated via mathematical models and fuzzy rule based method. The last method is model verification and validation. We aim to make sure that the model used in this research is up to the theoretical and practical standards set. This process is done manually The entire process will be done using the Python 3.0 programming language and utilizing plugins such as Scikit-Learn [26], sentiment analysis specifics such as Textblob, which uses the Natural language Toolkit (NLTK) principals and utilizes the Python programming language, and Scikit-Fuzzy.

\section{RESUlTS AND DisCUSSION}

\section{A. Results}

In this research the models will be used for 2 phases: the extraction and cleansing of the tweets/text data from the Twitter site, and the calculation of the waste management qualities and the decisions needed to be taken in specific categories.

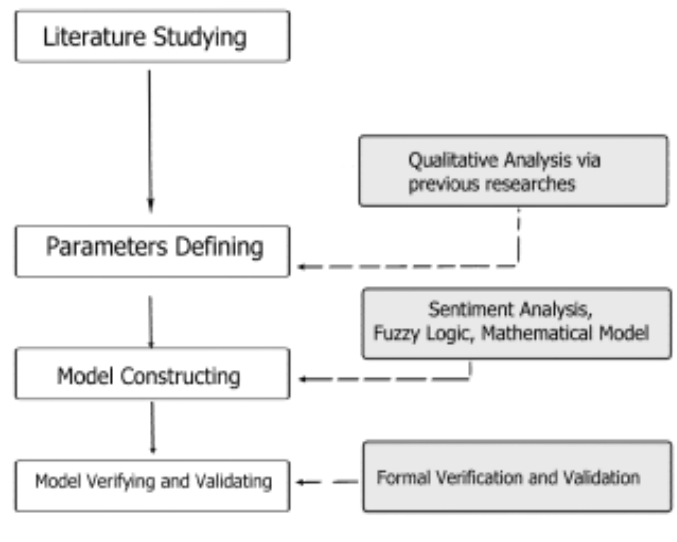

Image 2: Research Steps 


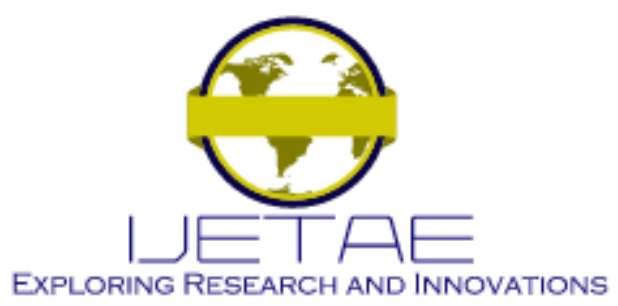

International Journal of Emerging Technology and Advanced Engineering Website: www.ijetae.com (E-ISSN 2250-2459, Scopus Indexed, ISO 9001:2008 Certified Journal, Volume 11, Issue 10, October 2021)

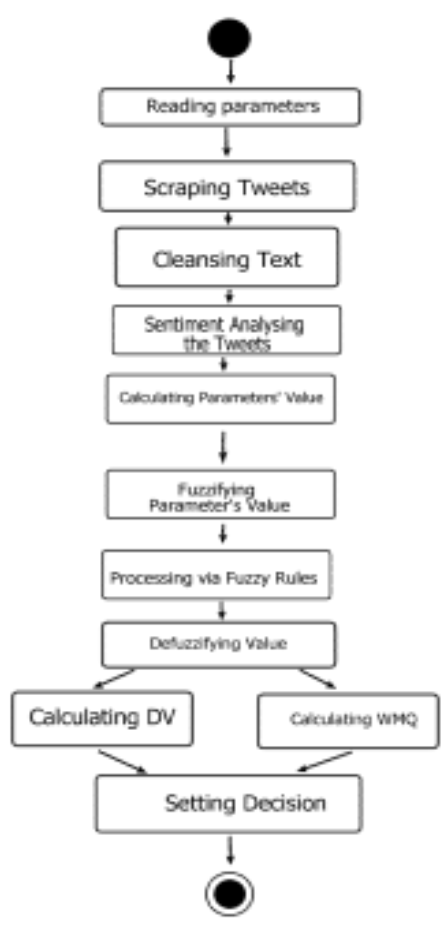

Image 3: Model Flow used

The sentiment analysis process will be conducted after the cleansing method. The process will determine the actual tweets based on the training data provided. The results of the sentiment analysis process, which is in form of polarity value that determines the positivity or negativity of the tweets, will serve as inputs for the decision support model.

The DSM will convert the attained values from the sentiment analysis results using fuzzy rules and mathematical models, and will generate final decision values. The explanation above is illustrated in Image 3 demonstrating the planned model flow for this research.

After the decision values for each of the parameters are calculated, a set of decisions are going to be determined based on the parameter values and the final overall quality value (Table 3 ). There are 2 classes of the decision values: "Improved" indicating poor decision values, and "Maintained" indicating adequate decision values. These values determine the decision in each aspect that must be taken by the parties connected to it. For example, bad "Leadership" value means certain actions has to be taken by the governments and lawmakers while bad "Public Knowledge" values mean improvements needed in terms of public education.

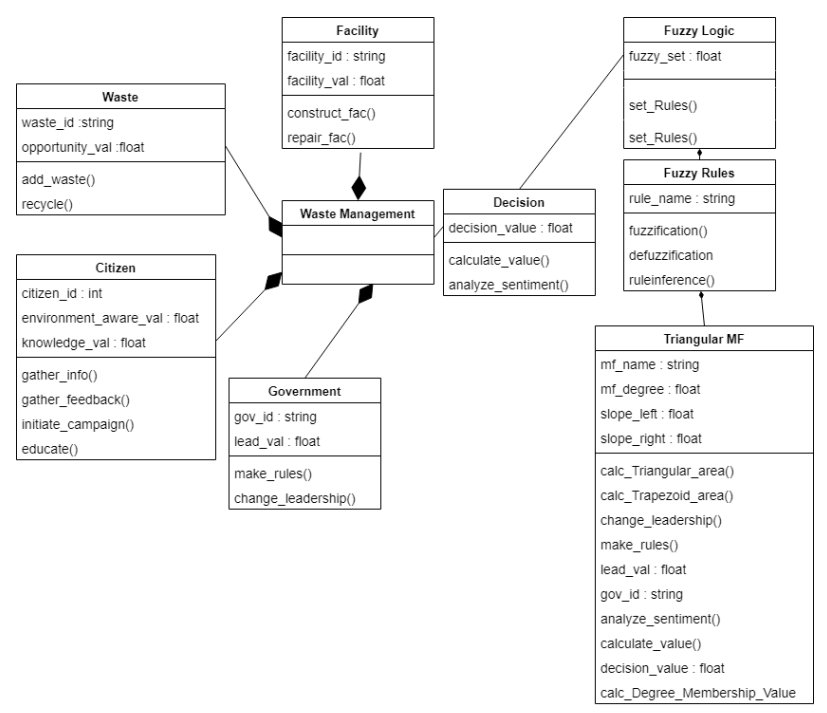

Image 4: Class Diagram of Model

Image 4 shows the class diagram of the system being planned. It shows Decision as the class that is going to be the most important and is associated with the Waste Management and Fuzzy Logic. The Waste Management class is going to have real life factors such as Facility and Waste as the mandatory connections for the class to function properly. Sentiment analysis will be marked as analyze_sentiment and will have an important connection to Fuzzy Logic, which is part of the DSM. The Fuzzy Logic itself will also have influence from the Fuzzy Rules and Fuzzy Membership Function in order to work effectively. Several other classes like Waste and Citizen are important factors for the waste management input and can influence the available decision models.

The sentiment analysis started with scraping the tweets from the Twitter website in Bahasa Indonesia to maximize the population of the tweets originating from Indonesia with the time range of July to August 2020. The scraping process used keywords "Sampah", "Manajemen" and "Lingkungan" and resulted in 496 tweets, which would then preprocessed using the aforementioned plugins. Textblob was utilized to perform sentiment analysis on the preprocessed tweets, which would then be translated to the English language to cope with Textblob's requirements. The sentiment analysis resulted in polarity value ranging from -1 to 1 and the crisp inputs (CI) are converted from these values into 0 to 2 value. 


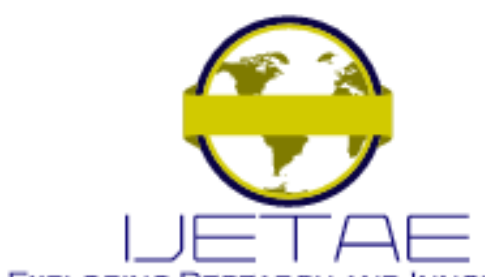

\section{EXPLORING RESEARCH AND INNOVATIONS}

\section{International Journal of Emerging Technology and Advanced Engineering}

Website: www.ijetae.com (E-ISSN 2250-2459, Scopus Indexed, ISO 9001:2008 Certified Journal, Volume 11, Issue 10, October 2021)

The tweets are divided into 5 categories listed in (Table 2), reflecting each aspect related to the waste management. These parameters are "Environmental Awareness", "Public's Knowledge", "Law Enforcement", "Opportunity", "Public Facility", "Spirit" and "Leadership", and was aimed to cover the government, public, and environmental aspects. Upon analysis, Table 3 is the crisp input (CI) values of each category.

Table 2:

Categories being assessed and their coefficients

\begin{tabular}{|l|l|c|}
\hline \multicolumn{1}{|c|}{ Category } & \multicolumn{1}{|c|}{ Sources } & Coefficient \\
\hline Environmental Awareness (EA) & {$[27],[28]$} & 0.23 \\
\hline Leadership (LD) & {$[29]$} & 0.45 \\
\hline Opportunity (OP) & {$[30]$} & 0.13 \\
\hline Public Facility (PF) & {$[31],[32]$} & 0.07 \\
\hline Public Knowledge (PK) & {$[33],[34]$,} & 0.11 \\
& {$[35]$} & \\
\hline
\end{tabular}

Table 3:

Crisp Input Values

\begin{tabular}{|l|c|l|l|}
\hline \multicolumn{1}{|c|}{ Category } & $\begin{array}{c}\text { CI } \\
\text { Value }\end{array}$ & $\begin{array}{c}\text { Fuzzy Value } \\
\text { Low }\end{array}$ & \multicolumn{1}{|c|}{$\begin{array}{c}\text { Fuzzy } \\
\text { Value } \\
\text { High }\end{array}$} \\
\hline $\begin{array}{l}\text { Environmental } \\
\text { Awareness }\end{array}$ & 1.10 & $0.25 \mathrm{~L}$ & $0.75 \mathrm{M}$ \\
\hline Leadership & 0.99 & $0.525 \mathrm{~L}$ & $0.475 \mathrm{M}$ \\
\hline Opportunity & 0.14 & $1 \mathrm{VL}$ & - \\
\hline Public Facility & 1.02 & $0.45 \mathrm{~L}$ & $0.55 \mathrm{M}$ \\
\hline Public Knowledge & 1.07 & $0.325 \mathrm{~L}$ & $0.675 \mathrm{M}$ \\
\hline
\end{tabular}

Table 4:

The Range of Crisp Input Values

\begin{tabular}{|l|r|l|l|}
\hline \multicolumn{1}{|c|}{ Class } & Range Min & Peak & \multicolumn{1}{c|}{ Range Max } \\
\hline $\begin{array}{l}\text { Very } \\
\text { Low }\end{array}$ & 0.0 & $0-0.4$ & 0.8 \\
\hline Low & 0.4 & 0.8 & $0.51 \mathrm{M}$ \\
\hline Medium & 0.8 & 1.2 & - \\
\hline High & 30.8 & 1.6 & $0.59 \mathrm{M}$ \\
\hline Very high & 1.6 & 2 & 2 \\
\hline
\end{tabular}

Table 5:

Significance Values

\begin{tabular}{|l|c|l|l|}
\hline Category & $\begin{array}{l}\text { Significance } \\
\text { Value }\end{array}$ & $\begin{array}{l}\text { Fuzzy } \\
\text { Value } \\
\text { Low }\end{array}$ & $\begin{array}{l}\text { Fuzzy } \\
\text { Value } \\
\text { High }\end{array}$ \\
\hline $\begin{array}{l}\text { Environmental } \\
\text { Awareness }\end{array}$ & 43.0 & $0.77 \mathrm{M}$ & - \\
\hline Leadership & 35.4 & $0.23 \mathrm{~B}$ & $0.51 \mathrm{M}$ \\
\hline Opportunity & 45.8 & $0.86 \mathrm{M}$ & - \\
\hline Public Facility & 37.6 & $0.12 \mathrm{~B}$ & $0.59 \mathrm{M}$ \\
\hline Public Knowledge & 41.5 & $0.72 \mathrm{M}$ & - \\
\hline
\end{tabular}

Table 6:

The Range of Significance Values

\begin{tabular}{|l|l|l|l|}
\hline Class & $\begin{array}{l}\text { Range } \\
\text { Min }\end{array}$ & Peak & $\begin{array}{l}\text { Range } \\
\text { Max }\end{array}$ \\
\hline Bad & 0 & $0-40$ & 20 \\
\hline Middle & 20 & 50 & 80 \\
\hline Good & 60 & $80-100$ & 100 \\
\hline
\end{tabular}

Table 7:

Decision Values

\begin{tabular}{|l|c|c|c|}
\hline Category & $\begin{array}{c}\text { Decision } \\
\text { Value }\end{array}$ & $\begin{array}{c}\text { Fuzzy Value } \\
\text { Low }\end{array}$ & $\begin{array}{c}\text { Fuzzy } \\
\text { Value High }\end{array}$ \\
\hline $\begin{array}{l}\text { Environmental } \\
\text { Awareness }\end{array}$ & 29.0 & $0.92 \mathrm{IM}$ & $0.07 \mathrm{MA}$ \\
\hline Leadership & 31.5 & $0.87 \mathrm{IM}$ & $0.13 \mathrm{MA}$ \\
\hline Opportunity & 28.2 & $0.94 \mathrm{IM}$ & $0.06 \mathrm{MA}$ \\
\hline Public Facility & 30.8 & $0.88 \mathrm{IM}$ & $0.12 \mathrm{MA}$ \\
\hline Public Knowledge & 29.5 & $0.91 \mathrm{IM}$ & $0.09 \mathrm{MA}$ \\
\hline
\end{tabular}

Table 8:

Range Values for Decision Values

\begin{tabular}{|c|c|c|c|}
\hline Class & $\begin{array}{l}\text { Range } \\
\text { Min }\end{array}$ & Peak & $\begin{array}{l}\text { Range } \\
\text { Max }\end{array}$ \\
\hline Improved & 0 & $0-25$ & 75 \\
\hline Maintained & 25 & $75-100$ & 100 \\
\hline
\end{tabular}

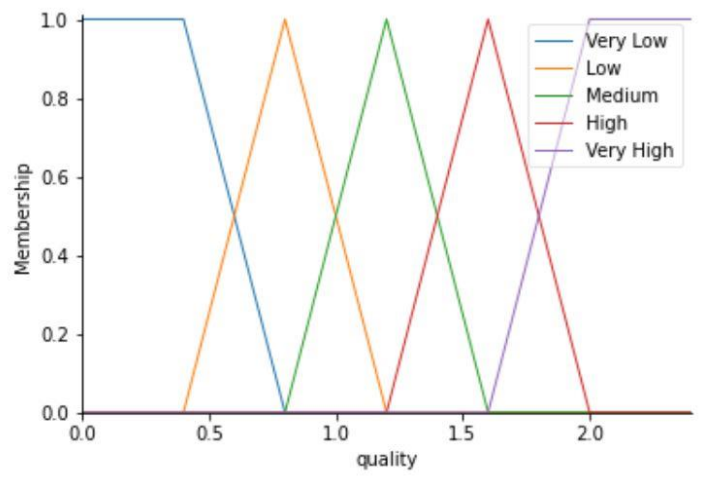

Image 5: Visualization of Fuzzy membership for Crisp Input 


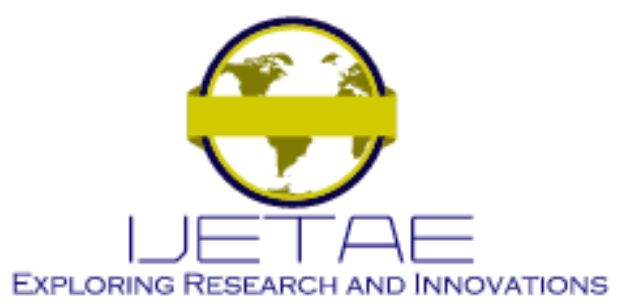

International Journal of Emerging Technology and Advanced Engineering

Website: www.ijetae.com (E-ISSN 2250-2459, Scopus Indexed, ISO 9001:2008 Certified Journal, Volume 11, Issue 10, October 2021)

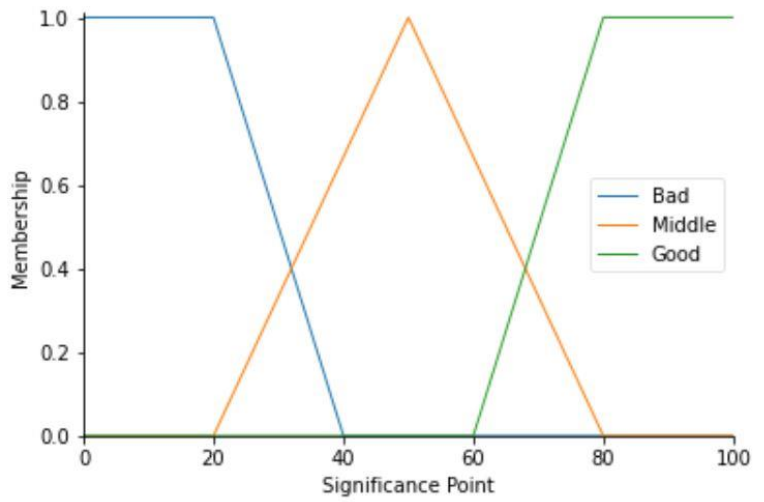

Image 6: Visualization of Fuzzy membership for Significance Value

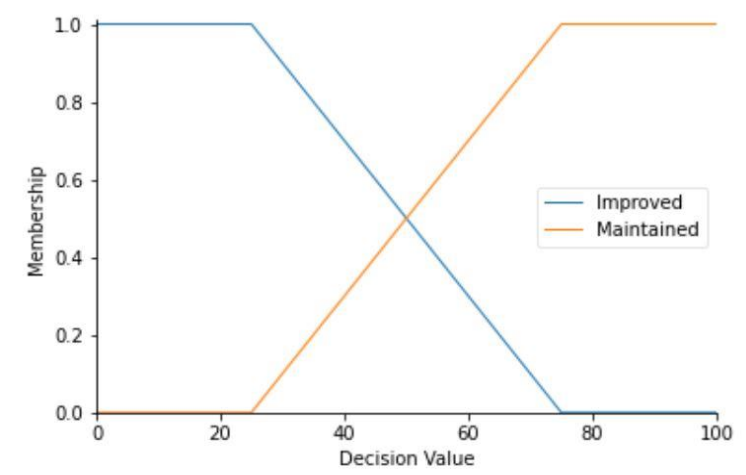

Image 7: Visualization of Fuzzy membership for Decision Value

The CI value itself is divided into 5 different classes ranging from very low (VL) to very high $(\mathrm{VH})$. It would then be converted to significance values, which consists of 3 classes: bad (B), middle (MI), and good (G). Each of these values will be converted again to the decision values (DV) which would be used to determine the decision that needs to be taken. The decision values are either improved (IM) or maintained (MA). Each conversion processes used the fuzzification, rule based inference and defuzzification process, utilizing the fuzzy logic mentioned previously.

Tables 5 up to 8 show respectively the classes of CI, Significance Value, range of significance value, decision value (DV), and range of DV. On the other hand, the range stated in the tables are visualized in Images 5, 6, and 7. To Calculate DV, The formula of the Decision Value for each parameter is described via Equation (4); Where $D V_{i}$ is the ith decision value and $C E_{i}$ indicates the ith centroid of the parameter.

$$
D V_{\text {def }}=\frac{\sum_{i=1}^{n} D V_{i} \times C E_{i}}{\sum_{i=1}^{n} D V_{i}}
$$

The overall value of Waste Management Quality (WMQ) is calculated at the end of this process as well using the formula described in Equation (5); where Coeff $_{i}$ refers to the total of occurrence of the parameter compared to the total, whilst $C I_{i}$ indicates the grade of the polarity values obtained from the sentiment analysis.

$$
W M Q=\sum_{1}^{i} \operatorname{Coeff} f_{i} \times I_{i}
$$

As clearly shown from the DVs listed in the table above, the fact that none of the categories, according to the TextBlob assisted sentiment analysis, didn't even have the score of higher than 40, meaning improvements in every category is needed in order to elevate the waste management performance to a much better state. The WMQ value calculated was 45.29 , meaning that overall, the waste management quality in Indonesia according to Indonesian Twitter users alone, are in less than desirable state and needs to be addressed.

\section{B. Model Verification and Validation}

To confirm the authenticity of the model used we performed a manual test of the data being used in this research to compare the test results to the actual results being generated by the model. There are 2 tests conducted in this phase: for the Textblob module used in the Sentiment Analysis process and the Fuzzy Logic used in the DSM.

The Sentiment Analysis test was done by taking a small sized sample from all the data and perform manual check on the sentences and determine based on individual words whether the sentence has a positive or negative sentiment. As shown in Table 10, the test concluded with 5 out of 6 sentences having the same sentiment as the results provided by the actual model. The verification and validation test has proven the capability of the TextBlob model in classifying the sentences given. 


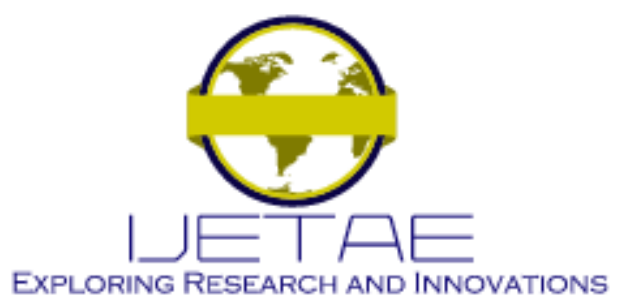

International Journal of Emerging Technology and Advanced Engineering

Website: www.ijetae.com (E-ISSN 2250-2459, Scopus Indexed, ISO 9001:2008 Certified Journal, Volume 11, Issue 10, October 2021)

Table 10:

Verification and Validation Test for SA Model

\begin{tabular}{|c|l|l|l|}
\hline Test Number & Test Result & Model Result & $\begin{array}{c}\text { Same } \\
\text { Category? }\end{array}$ \\
\hline 1 & Neutral & Neutral & Yes \\
\hline 2 & Negative & Negative & Yes \\
\hline 3 & Negative & Negative & Yes \\
\hline 4 & Positive & Positive & Yes \\
\hline 5 & Positive & Positive & Yes \\
\hline 6 & Negative & Neutral & No \\
\hline
\end{tabular}

Table 11:

Verification and Validation Test for DSM

\begin{tabular}{|c|c|c|c|}
\hline CI Value & Test Result & $\begin{array}{c}\text { Model } \\
\text { Result }\end{array}$ & $\begin{array}{c}\text { True Positive } \\
\text { Value }\end{array}$ \\
\hline 1.10 & 42.50 & 43.00 & 0.88 \\
\hline 0.99 & 34.25 & 35.40 & 0.66 \\
\hline 1.14 & 45.50 & 45.80 & 0.99 \\
\hline 1.02 & 36.50 & 37.60 & 0.97 \\
\hline 1.07 & 40.25 & 41.50 & 0.97 \\
\hline
\end{tabular}

The Fuzzy Logic Model was tested using the crisp input values in all 5 categories as the test values. As seen in Table 11, The test used the formula as the baseline and concluded that the model used worked as expected. It is noted that the model used a fully accurate value during the processing while the verification and validation test used the values that are rounded up to 2 numbers behind comma. The lowest value recorded from this test was 0.66 (the CI value for "Leadership") from the maximum value of 1 and the most accurate one being the "Opportunity" category.

\section{Suggestion}

Based Algorithm 3's rule and the results being presented in Table 8, the decisions we propose based on the severity of the quality in each of the parameters assessed can be viewed in Table 10. We proposed scenarios for the "Slightly Improved" decision categories and "Greatly Improved" decision categories. In line of that here are the decisions we propose based on the severity of the quality in each of the parameters assessed (Table 12) .

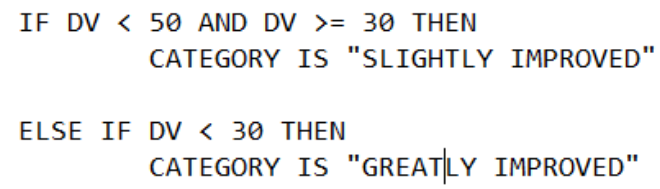

Code 1: The Pseudocode to Determine the Decision Taken
Table 12:

Proposed Suggestions

\begin{tabular}{|l|l|l|}
\hline Category & $\begin{array}{l}\text { "Slightly Improved" } \\
\text { Decision }\end{array}$ & $\begin{array}{l}\text { "Greatly } \\
\text { Improved" } \\
\text { Decision }\end{array}$ \\
\hline $\begin{array}{l}\text { Environmental } \\
\text { Awareness }\end{array}$ & $\begin{array}{l}\text { Increasing Social Media } \\
\text { campaign }\end{array}$ & $\begin{array}{l}\text { Increasing direct } \\
\text { interactions with } \\
\text { citizens }\end{array}$ \\
\hline Leadership & $\begin{array}{l}\text { Improving } \\
\text { communication with } \\
\text { local leaders }\end{array}$ & $\begin{array}{l}\text { Create or improve } \\
\text { waste } \\
\text { management laws } \\
\text { that bans non } \\
\text { environmental } \\
\text { friendly practices }\end{array}$ \\
\hline Opportunity & $\begin{array}{l}\text { Improving the available } \\
\text { recycling mechanisms } \\
\text { and encourage more } \\
\text { public participation }\end{array}$ & $\begin{array}{l}\text { Developing or } \\
\text { adapting modern } \\
\text { waste } \\
\text { management } \\
\text { technology }\end{array}$ \\
\hline Public Facility & $\begin{array}{l}\text { Improving and } \\
\text { renewing available } \\
\text { public facilities }\end{array}$ & $\begin{array}{l}\text { Promoting } \\
\text { community } \\
\text { assisted waste } \\
\text { facilities }\end{array}$ \\
\hline Public & $\begin{array}{l}\text { Hold seminars related } \\
\text { to waste and } \\
\text { environmental issues }\end{array}$ & $\begin{array}{l}\text { Insert the waste } \\
\text { and environmental } \\
\text { educations to } \\
\text { school } \\
\text { curriculums }\end{array}$ \\
\hline
\end{tabular}

For the environmental awareness aspect, the more awareness people have will mean more participations in making the waste management activity working effectively. One research outlined the importance of making public engaged in the activity or dialogs being organized rather than just simple one way communications [36]. There is also the need to change the public perception when communicating the message [37], which will be discussed later, so that the information about the necessity of these improvements will be able to spread faster, therefore resulting in higher chances of the awareness in people that don't have yet being triggered. While social media approach can be effective in spreading the messages (via likes, reposts, etc.), to see the concrete actions and participations being taken, direct communication methods like seminars and direct campaigns will be much better methods since the public can directly engage in these efforts. 


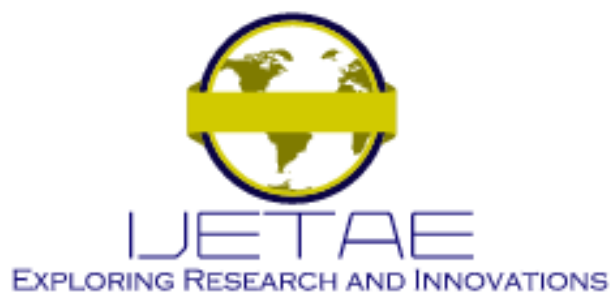

International Journal of Emerging Technology and Advanced Engineering

Website: www.ijetae.com (E-ISSN 2250-2459, Scopus Indexed, ISO 9001:2008 Certified Journal, Volume 11, Issue 10, October 2021)

For the leadership aspects, the obvious thing is reviewing the available laws and their enforcements towards the public activities. Such examples of corrupt law enforcements can be seen in [38] where the lack of consistency in the stewarding and illegal schemes existing at that time caused negative consequences, meaning that there is still a lot of things inside the government's policy enforcements that needs to be fixed. However, what is required to elevate the condition of the waste management is communication between central and local governments. There are some things that is more effective when being done by local governments such as managing their own waste management activity and directly policing the ban of nonrenewable products [39]. Better communication between these entities by updating the progress of each province's waste management status and making policies and making sure the citizens doesn't disobey them to prevent the negative effects.

In relation for the previous aspects, the important issues to be fixed when it comes on capitalizing on opportunities are alternative options and available technologies. An example of alternative solutions to existing waste products can be in form of replacement materials such as biogas [40] or biodegradable plastics over single use ones. As for the technologies side we believe that Indonesia can adapt technologies being proposed for modern cities on other parts of the world. While smart city isn't a common occurrence in this nation yet there is a lot of potential that can be utilized from the available current technologies. At the moment, the likes of IoT can improve the waste collection process to make it less complicated [41], smart waste management system [42], or reducing unnecessary waste. By reviewing the waste management technologies available in other countries and adapt it here, there is a chance to take the management to the next level and leaving the slower working ones.

When it comes to public facilities, while the improvements we can do is to replace the broken dustbins and old waste management equipment is imperative as well to activate more facilities that is intended for local communities. A case in Malang [43] showed the effectiveness of waste bank in supporting local economy. Supporting the communities with facilities tailored to them should be able to increase public participation and provide incentives to the quality of activities in the area as well.
Finally, for public knowledge the most crucial thing is for education to not only increase the awareness but also the knowledge of what they can do to mitigate these environmental issues from the simple case of separating organic and non-organic waste when dumping them to the techniques that can be used to recycle certain materials. With correct approach we could achieve a scenario of turning around $45 \%$ of people who are unsure about plastic bag bans to be in favor of the policy being implemented in Nigeria [44]. Under current situation it'll be more imperative to implement this in earlier educations such as primary schools, which means a possibly more effective method by applying this education as early as possible.

\section{CONCLUSION}

This paper proposed the Sentiment Analysis combined with DSM model to be implemented into the waste management case in Indonesia. The Sentiment Analysis proved itself particularly useful in determining specific values that indicates the positivity or negativity of Twitter users' sentiment regarding the situation. The DSM also categorized these values into classes that contains easier to understand information for public's knowledge of the situation. Compared to the previous researches where it required direct iteration between researchers and the public, Sentiment Analysis algorithms, including the Naïve Bayes principles and the existing machine learning tools available proved to be useful in analyzing real time emotions of public social media platform users therefore making the information gathering process quicker. The Web Scraper plugin was also able to generate more updated sentiment data related to this research, which means there is more probability of this research being conducted using a different set of data in a different set of time as well.

Indonesia's waste management model currently is in a state of requiring necessary improvements for governing bodies and all of the citizens alike. From increasing the awareness of more environmental friendly product usage to the policy of the simplest things that is waste related. We highly suggest for every region in the country to be involved so that the standard of the waste policy can be raised into a much higher level. 


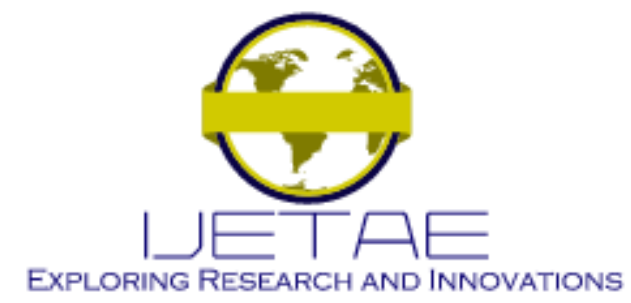

\section{International Journal of Emerging Technology and Advanced Engineering} Website: www.ijetae.com (E-ISSN 2250-2459, Scopus Indexed, ISO 9001:2008 Certified Journal, Volume 11, Issue 10, October 2021)

This research used a non-waste related dataset during the training process, therefore it is heavily suggested that a more waste related data, complete with the sentiment, to be constructed, therefore similar themed researches can be conducted using either new or preexisting sentiment analysis algorithms such as Textblob's Naïve Bayes scheme, Support Vectoring Machine and other kinds. It is also possible for non Naïve Bayes related algorithms to be used for this research with Movie Review Dataset as the training data to re ensure the accuracy of this research when another iteration is conducted.

This form of research can also be used for other topics that are being discussed in Twitter, whether it is about sports, entertainment, or politics. There is a huge potential, including the existing sentiment analysis researches, for Twitter to be analyzed to reflect the public opinion of one or more important topics that is often being discussed in this world.

\section{REFERENCES}

[1] A. M. Kaplan and M. Haenlein, "Users of the world, unite! The challenges and opportunities of Social Media," Bus. Horiz., vol. 53, no. 1, pp. 59-68, Jan. 2010, doi: 10.1016/j.bushor.2009.09.003.

[2] A. Mislove, S. Lehmann, Y.-Y. Ahn, J.-P. Onnela, and J. N. Rosenquist, "Understanding the Demographics of Twitter Users." Accessed: Jan. 14, 2020. [Online]. Available: www.aaai.org.

[3] S. Mani and S. Singh, "Sustainable Municipal Solid Waste Management in India: A Policy Agenda," Procedia Environ. Sci., vol. 35, pp. 150-157, 2016, doi: 10.1016/j.proenv.2016.07.064.

[4] L. Xiao, G. Zhang, Y. Zhu, and T. Lin, "Promoting public participation in household waste management: A survey based method and case study in Xiamen city, China," J. Clean. Prod., vol. 144, pp. 313-322, Feb. 2017, doi: 10.1016/j.jclepro.2017.01.022.

[5] R. L. S. Fernando, "Solid waste management of local governments in the Western Province of Sri Lanka: An implementation analysis," Waste Manag., vol. 84, pp. 194-203, Feb. 2019, doi: 10.1016/j.wasman.2018.11.030.

[6] J. K. Kavota, J. R. K. Kamdjoug, and S. F. Wamba, "Social media and disaster management: Case of the north and south Kivu regions in the Democratic Republic of the Congo," Int. J. Inf. Manage., 2020, doi: 10.1016/j.ijinfomgt.2020.102068.

[7] İ. E. Erdoğmuş and M. Çiçek, "The Impact of Social Media Marketing on Brand Loyalty," Procedia - Soc. Behav. Sci., vol. 58, pp. 1353-1360, Oct. 2012, doi: 10.1016/j.sbspro.2012.09.1119.

[8] W. Young, S. V. Russell, C. A. Robinson, and R. Barkemeyer, "Can social media be a tool for reducing consumers' food waste? A behaviour change experiment by a UK retailer," Resour. Conserv. Recycl., vol. 117, pp. 195-203, Feb. 2017, doi: 10.1016/j.resconrec.2016.10.016.

[9] M. Sujata, K. S. Khor, T. Ramayah, and A. P. Teoh, "The role of social media on recycling behaviour," Sustain. Prod. Consum., vol. 20, pp. 365-374, Oct. 2019, doi: 10.1016/j.spc.2019.08.005.
[10] D. N. Utama, "Media social based smart DSM for strategic decision making: Waste management case,” Int. J. Recent Technol. Eng., vol. 8, no. 3, pp. 7308-7312, Sep. 2019, doi: 10.35940/ijrte.C5944.098319.

[11] D. N. Utama, "Social-Media based DSM for Strategic Decision Making: Corruption Case," no. 5, pp. 5588-5591, 2020, doi: 10.35940/ijrte.E6492.018520.

[12] Z. Wu and J. Xu, "A consistency and consensus based decision support model for group decision making with multiplicative preference relations," Decis. Support Syst., vol. 52, no. 3, pp. 757767, Feb. 2012, doi: 10.1016/j.dss.2011.11.022.

[13] L. Yu and K. K. Lai, "A distance-based group decision-making methodology for multi-person multi-criteria emergency decision support,” Decis. Support Syst., vol. 51, no. 2, pp. 307-315, May 2011, doi: 10.1016/j.dss.2010.11.024

[14] J. K. Watson and K. M. B. Taminger, "A decision-support model for selecting additive manufacturing versus subtractive manufacturing based on energy consumption," J. Clean. Prod., vol. 176, pp. 13161322, Mar. 2018, doi: 10.1016/j.jclepro.2015.12.009.

[15] H. gang Peng, H. yu Zhang, and J. qiang Wang, "Cloud decision support model for selecting hotels on TripAdvisor.com with probabilistic linguistic information,” Int. J. Hosp. Manag., vol. 68, pp. 124-138, Jan. 2018, doi: 10.1016/j.ijhm.2017.10.001.

[16] L. M. Smirnova and Z. M. Yuldashev, "A model for decision making support for evaluation of functional efficiency of lower limb orthotics," in Procedia Computer Science, 2019, vol. 150, pp. 253260, doi: 10.1016/j.procs.2019.02.050.

[17] S. Muralidharan, L. Rasmussen, D. Patterson, and J. H. Shin, "Hope for Haiti: An analysis of Facebook and Twitter usage during the earthquake relief efforts," Public Relat. Rev., vol. 37, no. 2, pp. 175177, Jun. 2011, doi: 10.1016/j.pubrev.2011.01.010.

[18] T. Singh and M. Kumari, "Role of Text Pre-processing in Twitter Sentiment Analysis," in Procedia Computer Science, 2016, vol. 89, pp. 549-554, doi: 10.1016/j.procs.2016.06.095.

[19] S. Rill, D. Reinel, J. Scheidt, and R. V. Zicari, "PoliTwi: Early detection of emerging political topics on twitter and the impact on concept-level sentiment analysis," Knowledge-Based Syst., vol. 69, no. 1, pp. 24-33, 2014, doi: 10.1016/j.knosys.2014.05.008.

[20] R. K. Bakshi, N. Kaur, R. Kaur, and G. Kaur, "Opinion mining and sentiment analysis," in Proceedings of the 10th INDIACom; 2016 3rd International Conference on Computing for Sustainable Global Development, INDIACom 2016, Oct. 2016, vol. 2, no. 1-2, pp. 452 455, doi: 10.1561/1500000011.

[21] S. Bird and E. Loper, "NLTK: The Natural Language Toolkit," 2004. Accessed: Apr. 14, 2020. [Online]. Available: www.python.org.

[22] L. A. Zadeh, "Fuzzy logic - a personal perspective," Fuzzy Sets Syst., vol. 281, pp. 4-20, Dec. 2015, doi: 10.1016/j.fss.2015.05.009.

[23] W. Van Leekwijck and E. E. Kerre, "Defuzzification: Criteria and classification," Fuzzy Sets Syst., vol. 108, no. 2, pp. 159-178, Dec. 1999, doi: 10.1016/s0165-0114(97)00337-0.

[24] M. G. Voskoglou, "Comparison of the COG Defuzzification Technique and Its Variations to the GPA Index," Nov. 2016, Accessed: Apr. 03, 2020. [Online]. Available: http://arxiv.org/abs/1612.00742. 


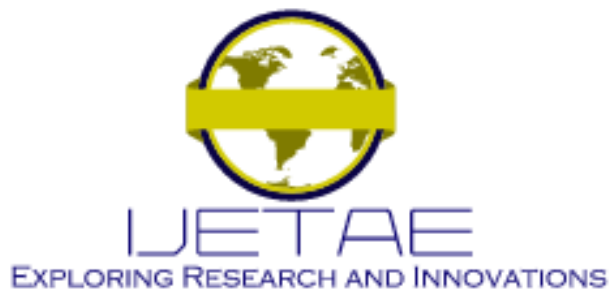

International Journal of Emerging Technology and Advanced Engineering Website: www.ijetae.com (E-ISSN 2250-2459, Scopus Indexed, ISO 9001:2008 Certified Journal, Volume 11, Issue 10, October 2021)

[25] "Web Scraper - The \#1 web scraping extension." https://webscraper.io/ (accessed Jan. 30, 2020).

[26] L. Buitinck et al., "API design for machine learning software: experiences from the scikit-learn project," Sep. 2013, Accessed: Feb. 24, 2020. [Online]. Available: http://arxiv.org/abs/1309.0238.

[27] C. Jaccoud and A. Magrini, "Regulation of solid waste management at Brazilian ports: Analysis and proposals for Brazil in light of the European experience," Mar. Pollut. Bull., vol. 79, no. 1-2, pp. 245253, Feb. 2014, doi: 10.1016/j.marpolbul.2013.12.006.

[28] I. Steensgaard, K. Syberg, S. Rist, N. Hartmann, A. Boldrin, and S. F. Hansen, "From macro- to microplastics - Analysis of EU regulation along the life cycle of plastic bags," Environmental Pollution, vol. 224. Elsevier Ltd, pp. 289-299, 2017, doi: 10.1016/j.envpol.2017.02.007.

[29] H. A. Solanki, P. Hardik, and S. Hitesh, "Government Initiatives and Activities to combat the issues of Municipal Solid Waste Management in India," Int. J. Res. Advent Technol., vol. 6, no. 5, 2018, Accessed: Oct. 21, 2020. [Online]. Available: www.ijrat.org.

[30] S. Raharjo, T. Matsumoto, T. Ihsan, I. Rachman, and L. Gustin, "Community-based solid waste bank program for municipal solid waste management improvement in Indonesia: a case study of Padang city," J. Mater. Cycles Waste Manag., vol. 19, no. 1, pp. 201-212, Jan. 2017, doi: 10.1007/s10163-015-0401-z.

[31] D. A. Colvero, J. Ramalho, A. P. D. Gomes, M. A. A. de Matos, and L. A. da C. Tarelho, "Economic analysis of a shared municipal solid waste management facility in a metropolitan region," Waste Manag., vol. 102, pp. 823-837, Feb. 2020, doi 10.1016/j.wasman.2019.11.033.

[32] M. Chaerul, A. R. Fahruroji, and T. Fujiwara, "Recycling of plastic packaging waste in Bandung City, Indonesia," J. Mater. Cycles Waste Manag., vol. 16, no. 3, pp. 509-518, 2014, doi: 10.1007/s10163-013-0201-2.

[33] B. Richter, "Knowledge and perception of food waste among German consumers," J. Clean. Prod., vol. 166, pp. 641-648, Nov. 2017, doi: 10.1016/j.jclepro.2017.08.009.

[34] L. E.O., L. O.O., and U. E.F., "People'S Perception On Household Solid Waste Management In Ojo Local Government Area In Nigeria," Iranian Journal Of Environmental Health Science And Engineering (IJEHSE), Jan. 2009. Accessed: Oct. 23, 2020. [Online]. Available: https://www.sid.ir/en/journal/ViewPaper.aspx?ID=166008.
[35] I. A. Al-Khatib, S. Kontogianni, H. Abu Nabaa, N. Alshami, and M. I. Al-Sari', "Public perception of hazardousness caused by current trends of municipal solid waste management," Waste Manag., vol. 36, pp. 323-330, Feb. 2015, doi: 10.1016/j.wasman.2014.10.026

[36] R. J. Brulle, "From environmental campaigns to advancing the public dialog: Environmental communication for civic engagement," Environ. Commun., vol. 4, no. 1, pp. 82-98, Mar. 2010, doi: 10.1080/17524030903522397.

[37] M. C. Nisbet and D. A. Scheufele, "What's next for science communication? promising directions and lingering distractions," Am. J. Bot., vol. 96, no. 10, pp. 1767-1778, Oct. 2009, doi: 10.3732/ajb.0900041.

[38] F. J. Priyono, "Law Enforcement Of Electrical And Electronic Waste Smuggling In Batam, Indonesia," Diponegoro Law Rev., vol. 2, no. 1, p. 40, Apr. 2017, doi: 10.14710/dilrev.2.1.2017.40-56.

[39] B. Sheehan and H. Spiegelman, "What Can Government Do to Eliminate Waste," 2004

[40] M. Khalil, M. A. Berawi, R. Heryanto, and A. Rizalie, "Waste to energy technology: The potential of sustainable biogas production from animal waste in Indonesia," Renewable and Sustainable Energy Reviews, vol. 105. Elsevier Ltd, pp. 323-331, May 01, 2019, doi: 10.1016/j.rser.2019.02.011

[41] T. Anagnostopoulos et al., "Challenges and Opportunities of Waste Management in IoT-Enabled Smart Cities: A Survey," IEEE Trans. Sustain. Comput., vol. 2, no. 3, pp. 275-289, Jul. 2017, doi: 10.1109/TSUSC.2017.2691049.

[42] V. M. Vinod and K. S. Tamilselvan, "An IoT enabled Smart Garbage Management System for Smart Cities-Indian Scenario," Int. J. Innov. Technol. Explor. Eng., 2020, doi: 10.35940/ijitee.D1856.029420.

[43] D. Wulandari, S. H. Utomo, and B. S. Narmaditya, "Waste bank: Waste management model in improving local economy," Int. J. Energy Econ. Policy, vol. 7, no. 3, pp. 36-41, 2017.

[44] A. M. Muhammad, "Public Acceptance Of A Proposed Ban On Plastic Bags In Nigeria: The Case Of Yola-Jimeta, Adamawa State," 2018. 